Dipublikasikan

Badan Pelaksana Kuliah Kerja Nyata

Universitas Lampung

Sekretariat Badan Pelaksana Kuliah Kerja Nyata, Universitas Lampung,

J. Prof. Dr. Soemantri Brojonegoro No. 1, Bandar Lampung 35145.

\title{
PEMETAAN DAERAH POTENSI RAWAN BANJIR DENGAN SISTEM INFORMASI GEOGRAFI METODE WEIGHTED OVERLAY DI KELURAHAN KETEGUHAN
}

\author{
Tarkono', As'ad Humam², Dafa Sitanala Putra Baladiah², Gema Annisa Hermastuti², \\ Indah Rahmayani², Ranti Vidia Mahyunis ${ }^{2}$, Shofiyyah Fauziah Sayuti ${ }^{2}$ \\ ${ }^{1}$ Jurusan Teknik Mesin/FT, Universitas Lampung, \\ ${ }^{2}$ Mahasiswa KKN Periode 2021 Universitas Lampung
}

Penulis Korespodensi : asadhumam777@gmail.com

\begin{abstract}
Abstrak
Kelurahan Keteguhan merupakan daerah yang sangat berpotensi mengalami bencana banjir, seperti pada kejadian banjir bandang yang pernah terjadi pada 30 Maret 2020. Pemetaan rawan banjir diperlukan untuk memetakan potensi rawan banjir di Kelurahan Keteguhan dengan tujuan untuk meningkatkan kesigapan dan kesiapan masyarakat Kelurahan Keteguhan dalam menghadapi bencana tersebut. Metode yang digunakan meliputi pengolahan parameter curah hujan, tutupan lahan, kemiringan lereng, jenis tanah, ketinggian lahan dan tutupan lahan, kemudian dilakukan proses pembobotan weighted overlay untuk membentuk data baru berupa peta potensi rawan banjir. Hasil yang didapatkan yaitu terdapat 3 daerah yang berpotensi yaitu bagian dataran rendah sepanjang area sungai jalan umbul kunci, area sungai pada lingkungan terdekat Kelurahan Keteguhan dan Mushollah Nurul Jannah pada jalan Laksamana R.E. Martadinata. Berdasarkan luas area tingkat kerawanan pada Kelurahan Keteguhan pada kategori aman memiliki luas hingga 137.451 Ha dengan persentase $44.6 \%$, kategori tidak rawan memiliki luas hingga $95.5116 \mathrm{Ha}$ dengan persentase $30.01 \%$, kategori rawan memiliki luas hingga $62.4922 \mathrm{Ha}$ dengan persentase $20.27 \%$ dan kategori sangat rawan memiliki luas hingga $15.7767 \mathrm{Ha}$ dengan persentase $5.12 \%$.
\end{abstract}

Kata kunci: Sistem Informasi Geografi, Weighted Overlay, Pemetaan Rawan Banjir.

\begin{abstract}
Keteguhan Village is an area that has the highly potential to flood disaster, such as the flash flood incident that occurred on March 30, 2020. Floodprone mapping is needed to map flood prone potentials in SKeteguhan Village with the aim of increasing the alertness and readiness of the Keteguhan Village's community in dealing that disaster. The used method includes processing the parameters of rainfall, land cover, slope, soil type, land height and land cover, then carried out by a weighted overlay process to form new data in the form of a flood prone potential map. The obtained results are that there are 3 potential areas, namely the lowlands along the river area of Umbul Kunci Street, the river area in the nearest neighborhood of Keteguhan Village and Mushollah Nurul Jannah on Laksamana R.E. Martadinata Street. Based on the area of vulnerability level in Keteguhan Village, the safe category has an area of up to 137,451 Ha with a percentage of $44.6 \%$, the non-prone category has an area of up to $95,5116 \mathrm{Ha}$ with a percentage of $30.01 \%$, the vulnerable category has an area of up to $62.4922 \mathrm{Ha}$ with a percentage of $20.27 \%$ and the very vulnerable category has area up to $15.7767 \mathrm{Ha}$ with a percentage of $5.12 \%$.
\end{abstract}

Keywords: Geographic Information System, Weighted Overlay, Flood Prone Mapping. 
Dipublikasikan

Badan Pelaksana Kuliah Kerja Nyata

Universitas Lampung

Sekretariat Badan Pelaksana Kuliah Kerja Nyata, Universitas Lampung,

J. Prof. Dr. Soemantri Brojonegoro No. 1, Bandar Lampung 35145.

\section{Pendahuluan}

Indonesia merupakan negara maritim yang terletak pada $6^{\circ} \mathrm{LU}-11^{\circ} \mathrm{LS}$ serta $95^{\circ} \mathrm{BT}-141^{\circ} \mathrm{BT}$ dengan pola geomorfologi beragam. Geomorfologi pada daerah Indonesia memiliki keberagamana dari dataran rendah hingga tinggi. Hal ini disebabkan karena kondisi Indonesia yang terletak pada 2 lempeng samudera dan 1 lempeng benua yaitu lempeng indo-australia, lempeng pasifik dan lempeng eurasia. Lempeng Eurasia berada dari arah asia tenggara yang bergerak $1 \mathrm{~cm} /$ tahun kea rah tenggara, lempeng india-australia bergerak $7 \mathrm{~cm} /$ tahun dan lempeng pasifik yang bergerak $9 \mathrm{~cm} /$ tahun. Dimana pergerakan lempeng dapat menimbulkan proses teknonik maupun vulkanik yang mana hal tersebut merupakan faktor pembentuk geomorfologi daerah Indonesia yang beragam. Proses tersebut merupakan pembentukan muka bumi secara endogen. Sehingga dengan adanya proses pergerakan lempeng banyak bencana yang terjadi baik secara langsung ataupun tidak langsung. Seperti halnya gunung api, gempa dan tsunami. Namun juga terdapat bencana alam yang tidak secara langsung seperti halnya banjir dan longsor yang disebabkan oleh geomorfologi, curah hujan berasal dari faktor alam, sedangkan dari faktor manusia berasal dari penyalah gunaan lahan dan pembuangan sampah sembarangan.

Bencana merupakan suatu peristiwa atau rangkaian peristiwa yang bersifat mengancam dan menganggu kehidupan serta penghidupan masyarakat disebabkan baik dari faktor alam maupun nonalam seperti halnya faktor manusia sehingga dapat menimbulkan korban jiwa, kerusakan lingkungan, kerugian harta benda, dan pisikologis (Maharani et al., 2020). Salah satu bencana yang sering terjadi di Indonesia yaitu banjir dan tanah longsor, hal ini sering di sebabkan oleh berbagai faktor yaitu secara alami Indonesia memiliki pola morfologi yang tinggi dan rendah sehingga pada daerah yang curam akan sering terjadi longsor dan daerah dataran rendah sering mengalami banjir, secara faktor non alami terjadi karena penggunaan lahan dan pembuangan sampah yang tidak baik oleh manusia. Pada pengabdian kali ini dilakukan pada daerah Kelurahan Keteguhan, Kecamatan Teluk Betung Timur, Bandar Lampung. Jika ditijau dalam segi bencana daerah Kelurahan Keteguhan sering mengalami bencana banjir, hal ini didapatkan berdasarkan wawancara pada masyarakat sekitar. Pada tahun 2020 tepatnya bulan maret tanggal 30 malam, terdapat dua Kelurahan pada Kecamatan Teluk Betung Timur yang mengalami bencana banjir bandang yang terjadi pada lingkungan 1 dan 3 pada kelurahan Sukamaju dengan total rumah yang rusak sebanyak 139 unit dengan kriteria 33 unit rumah rusak berat, 103 rusak ringan dan 3 rumah hanyut diterjang banjir serta pada Kelurahan Keteguhan terdapat lingkungan 1, 2 dan 3 yang terdampak dengan 15 unit rumah tersapu banjir dan 1 korban meninggal.

Banjir merupakan peristiwa tergenangnya daratan yang biasanya dalam kondisi kering oleh karena adanya volume air pada suatu bagian meningkat, sehingga air akan meluap yang disebabkan oleh hujan deras, pecahnya bendungan atau naiknya permukaan laut (Pahrul et al., 2017). Maka dari itu pemetaan daerah banjir sangat diperlukan untuk meningkatkan kesadaran masyarakat akan daerah yang berpotensi. Dalam proses pemetaan daerah rawan banjir pada daerah Keteguhan dilakukan dengan memanfaatkan Sistem Informasi Geografis (SIG) untuk memetakan daerah berpotensi berdasarkan menginderaan dari permukaan. Sistem Informasi Geografis (SIG) adalah system berbasis computer dengan kemampuan dalam menangani data yang bereferensi geografi berupa input data, manajemen data, memanipulasi dan analisis data, serta memiliki output (Tumimomor et al., 2013). Fungsi dan kegunaan Sistem Informasi Geografis untuk bencana banjir yaitu sebagai media untuk memetakan zona potensi banjir yang didasarkan data curah hujan, kemiringan lahan, ketinggian lahan, jenis tanah, penggunaan lahan dan buffer sungai, proses penyatuan data dilakukan menggunakan metode weighted overlay. Weighted Overlay merupakan salah satu metode pembobotan dengan mengoverlaykan beberapa peta yang berkaitan dengan faktor-faktor yang mempengaruhi terhadap parameter yang ditargetkan (Adininggar et al., 2016). Tujuan dari penelitian yang berbasis pengabdian ini yaitu guna meningkatkan kesadaran masyarakat akan arti pentingnya mitigasi bencana pra-bencana sebagai media agar masyarakat untuk lebih siap dalam menghadapi bencana banjir sehingga dapat meminimalisir kerugian yang ditimbulkan. 


\section{Jurnal Pengabdian Kepada Masyarakat BUGUH}

Dipublikasikan

Badan Pelaksana Kuliah Kerja Nyata

Universitas Lampung

Sekretariat Badan Pelaksana Kuliah Kerja Nyata, Universitas Lampung,

J. Prof. Dr. Soemantri Brojonegoro No. 1, Bandar Lampung 35145.

\section{Bahan dan Metode}

Metode dalam penelitian ini yaitu berupa pemetaan yang berbasis Sistem Informasi Geografis (SIG) dengan mempertimbangkan beberapa parameter data yang berkaitan terhadap bencana banjir pada daerah Kelurahan Keteguhan. Bahan yang digunakan meliputi data sekunder berupa curah hujan, digital elevation model, jenis tanah dan RBI.

Adapun penelitian berbasis pengabdian ini memiliki tahapan-tahapan sebagai berikut:

1) Survei pendahuluan yaitu berupa mengumpulan informasi terkait latar belakang bencana pada daerah penelitian melalui media wawancara kepada warga sekitar.

2) Pengumpulan data yaitu proses pencarian data yang akan dipergunakan sebagai media untuk pengolahan data meliputi; data digital elevation model, jenis tanah, curah hujan, dan RBI.

3) Pengolahan Data yang terdiri dari beberapa tahapan sebagai berikut;

- Peta Curah Hujan

Curah hujan merupakan salah satu parameter yang diukur, dimana curah hujan menyatakan besar tingginya air yang ditimbulkan oleh hujan pada suatu daerah (Ajr \& Dwirani, 2019). Data ini berasal dari Climate hazards Center UC Santa Barbara Tahun 2020. Proses berupa data yang berupa titik pengukuran dilakukan interpolasi menggunakan proses invers distance weighting yang kemudian dilakukan proses pengklasifikasian dan pembobotan, sebagai berikut:

Tabel 1. Klasifikasi Peta Curah Hujan

\begin{tabular}{lcc}
\hline No & Kelas & Skor \\
\hline 1 & $>3000 \mathrm{~mm}$ (Sangat Basah) & 9 \\
\hline 2 & $2501 \mathrm{~mm}-3000 \mathrm{~mm}($ Basah $)$ & 7 \\
\hline 3 & $2001 \mathrm{~mm}-2500 \mathrm{~mm}$ (Sedang/lembab) & 5 \\
\hline 4 & $1501 \mathrm{~mm}-2000 \mathrm{~mm}$ (Kering) & 3 \\
\hline 5 & $<1500 \mathrm{~mm}$ (Sangat Kering) & 1
\end{tabular}

\section{Sumber : (Hardianto et al., 2020)}

- Peta Jenis Tanah

Data jenis tanah berasal dari Food and Agriculture Organization of The United Nations yaitu berupa data jenis tanah dengan skala international, sehingga diperlukan proses cropping data agar sesuai pada daerah penelitian. Kemudian dilakukan proses pengklasifikasian dan skor pada data, sebagai berikut:

Tabel 2. Klasifikasi Peta Jenis Tanah

\begin{tabular}{lcc}
\hline No & Kelas & Skor \\
\hline 1 & Aluvial, Planosol, Hidromorf Kelabu, Laerik & 9 \\
& Air Tanah & \\
\hline 2 & Latosol & 7 \\
\hline 3 & Tanah Hutan Coklat, Tanah Mediteran & 5 \\
\hline 4 & Andosol, Laterik, Grumasol, Podsol, & 3 \\
& Podsolic & 1 \\
\hline 5 & Regosol, Litosol, Organosol, Renzina & \\
\hline
\end{tabular}

Sumber : (Hardianto et al., 2020)

- Peta Kemiringan Lahan 


\section{BUGUH}

Dipublikasikan

Badan Pelaksana Kuliah Kerja Nyata

Universitas Lampung

Sekretariat Badan Pelaksana Kuliah Kerja Nyata, Universitas Lampung,

J. Prof. Dr. Soemantri Brojonegoro No. 1, Bandar Lampung 35145.

Data untuk membuat kemiringan lereng merupakan data digital elevation model yang didapat dari badan informasi geospasial (BIG). Proses pengolahan berupa data DEM dilakukan cropping data pada daerah penelitian yang kemudian dilakukan proses slope dengan bentuk satuan persen. Sehingga dapat dilakukan pengklasifikasian dan pemberian skor, sebagai berikut:

Tabel 3. Klasifikasi Peta Kemiringan Lahan

\begin{tabular}{lcc}
\hline No & Kelas & Skor \\
\hline 1 & Datar $(0 \%-3 \%)$ & 9 \\
\hline 2 & Berombak $(3 \%-8 \%)$ & 7 \\
\hline 3 & Bergelombang $(8 \%-15 \%)$ & 5 \\
\hline 4 & Berbukit Kecil $(15 \%-30 \%)$ & 3 \\
\hline 5 & Berbukit $(30 \%-45 \%)$ & 2 \\
\hline 6 & Berbukit Curam/Terjal $(>45 \%)$ & 1 \\
\hline
\end{tabular}

Sumber : (Hardianto et al., 2020)

- Peta Ketinggian Lahan

Data untuk membuat ketinggian lahan merupakan data digital elevation model yang didapat dari badan informasi geospasial (BIG). Prosesnya meliputi cropping data yang kemudian dilakukan pengklasifikasian dan skor pada data, sebagai berikut:

Tabel 4. Klasifikasi Peta Ketinggian Lahan

\begin{tabular}{lcc}
\hline No & Kelas & Skor \\
\hline 1 & $0 \mathrm{~m}-12,5 \mathrm{~m}$ & 9 \\
\hline 2 & $12,5 \mathrm{~m}-25 \mathrm{~m}$ & 7 \\
\hline 3 & $25 \mathrm{~m}-50 \mathrm{~m}$ & 5 \\
\hline 4 & $50 \mathrm{~m}-75 \mathrm{~m}$ & 3 \\
\hline 5 & $75 \mathrm{~m}-100 \mathrm{~m}$ & 2 \\
\hline 6 & $>100 \mathrm{~m}$ & 1
\end{tabular}

Sumber : (Hardianto et al., 2020)

- Peta Penggunaan Lahan

Data untuk membuat peta penggunaan lahan merupakan data rupa bumi Indonesia (RBI) yang didapat dari badan informasi geospasial (BIG). Proses meliputi penseleksian parameter tutupan lahan dengan metode overlay yang kemudian diklasifikasikan dan skor, sebagai berikut:

Tabel 5. Peta Penggunaan Lahan

\begin{tabular}{lcc}
\hline No & Kelas & Skor \\
\hline 1 & Pemukiman/Non-Lahan & 9 \\
\hline 2 & Sawah/ Tambak & 7 \\
\hline 3 & Ladang/ Telaga/ Kebun & 5 \\
\hline 4 & Semak Belukar & 3 \\
\hline 5 & Hutan & 1 \\
\hline
\end{tabular}

Sumber : (Hardianto et al., 2020) 


\section{Jurnal Pengabdian Kepada Masyarakat BUGUH}

Dipublikasikan

Badan Pelaksana Kuliah Kerja Nyata

Universitas Lampung

Sekretariat Badan Pelaksana Kuliah Kerja Nyata, Universitas Lampung,

J. Prof. Dr. Soemantri Brojonegoro No. 1, Bandar Lampung 35145.

- Peta Buffer Sungai

Data yang dipergunakan untuk membuat peta buffer sungai meliputi data rupa bumi Indonesia (RBI) dengan mengambil parameter jalur sungai. Buffer sungai sendiri merupakan jarak sungai kearah daratan. Kemudian dilakukan proses multiple ring buffer lalu pengklasifikasian dan skor, sebagai berikut:

Tabel 6. Peta Buffer Sungai

\begin{tabular}{lcc}
\hline No & Kelas & Skor \\
\hline 1 & $0-25 \mathrm{~m}$ & 7 \\
\hline 2 & $25 \mathrm{~m}-100 \mathrm{~m}$ & 5 \\
\hline 3 & $100 \mathrm{~m}-250 \mathrm{~m}$ & 3
\end{tabular}

Sumber : (Hardianto et al., 2020)

- Proses Weighted Overlay

Proses ini merupakan penggabungan berdasarkan parameter peta diatas yang disatukan menjadi data baru dengan pertimbangan skor dari masing-masing parameter. Hasil dari proses weighted overlay akan menjadi peta potensi rawan banjir dengan menggunakan pembobotan antar parameter, sebagai berikut:

Tabel 7. Nilai Pembobotan Weighted Overlay

\begin{tabular}{lcc}
\hline No & Parameter & Skor \\
\hline 1 & Kemiringan Lahan & 0.2 \\
\hline 2 & Ketinggian Lahan & 0.15 \\
\hline 3 & Curah Hujan & 0.15 \\
\hline 4 & Buffer Sungai & 0.15 \\
\hline 5 & Penggunaan Lahan & 0.15 \\
\hline 6 & Jenis Tanah & 0.2 \\
\hline
\end{tabular}

4) Quality Control berupa kegiatan mensurvei daerah yang berpotensi berdasarkan hasil pengolahan dengan tujuan untuk memaksimalkan keakuratan data yang menyesuaikan dengan keadaan yang sebenarnya.

5) Pencetakan peta potensi rawan banjir

6) Penyerahan peta potensi rawan banjir Kelurahan Keteguhan.

7) Sosialisasi peta potensi rawan banjir Kelurahan Keteguhan kepada beberapa pihak kelurahan.

\section{Hasil dan Pembahasan}

Kelurahan keteguhan merupakan kelurahan yang berada pada Kecamatan Teluk Betung Timur, Bandar Lampung. Keteguhan memiliki luasan yang besar dengan berbagai medan baik dari dataran tinggi dan dataran rendah. Program penelitian ini merupakan pembuatan peta potensi rawan banjir yang memanfaatkan sistem informasi geografis dengan tujuan untuk memetakan daerah yang berpotensi pada daerah kelurahan keteguhan. Dalam pembuatan peta potensi rawan banjir digunakan beberapa parameter penyusunnya meliputi: peta jenis tanah, peta kemiringan lahan, peta ketinggian lahan, peta curah hujan, peta buffer sungai dan peta penggunaan lahan. Berdasarkan dari beberapa parameter dilakukan proses pembobotan dengan menggunakan metode weighted overlay dengan skor yang telah disediakan, sehingga hasil yang akan dicapai berupa peta potensi rawan banjir. Terdapat beberapa parameter yang mengontrol terjadinya bencana banjir. 


\section{BUGUH}

Dipublikasikan

Badan Pelaksana Kuliah Kerja Nyata Universitas Lampung

Sekretariat Badan Pelaksana Kuliah Kerja Nyata, Universitas Lampung, J. Prof. Dr. Soemantri Brojonegoro No. 1, Bandar Lampung 35145.

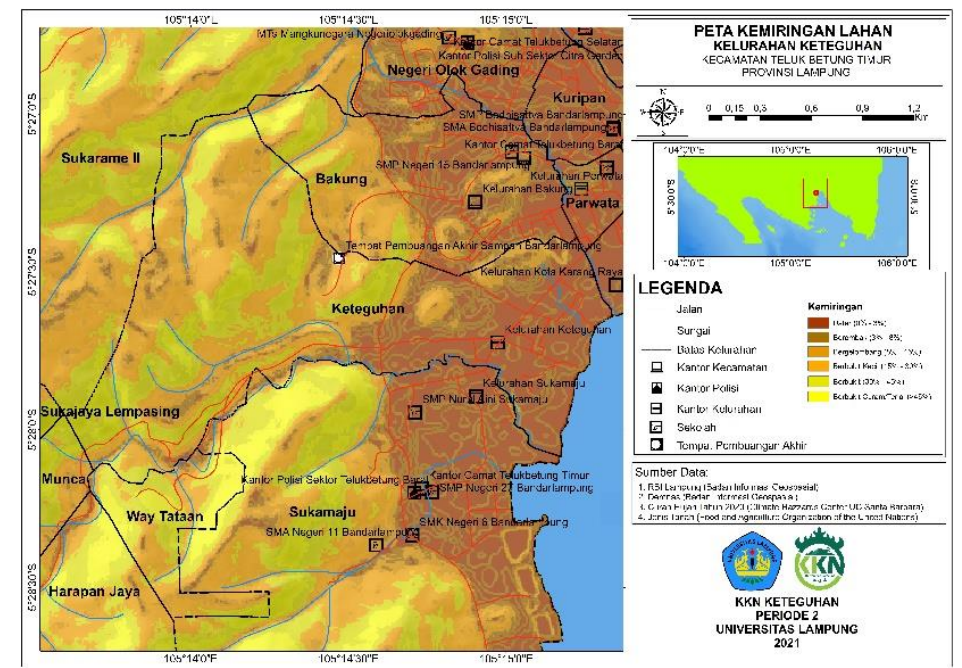

Gambar 1. Peta kemiringan lereng hasil proses slope dari data DEM

Pada daerah keteguhan terdapat beberapa pola kemiringan lereng yang bervariasi dimana pada daerah keteguhan yang memiliki kemiringan lereng tinggi berada pada daerah dataran tinggi keteguhan yaitu daerah umbul kunci lingkungan 3, sedangkan pada kemiringan lereng rendah terdapat pada daerah dataran rendah keteguhan pada lingkungan 1 dan 2. Kemiringan lereng menjadi parameter untuk peta rawan banjir dikarenakan semakin tinggi kemirigan lereng maka arus yang dihasilkan oleh sungai akan semakin deras debit airnya. Sehingga semakin besar nilai kemiringan lereng maka akan semakin besar daerah tersebut berpotensi dalam terjadinya bencana rawan banjir. Pada daerah keteguhan daerah yang memiliki kelas kemiringan lereng yang besar berada pada daerah dataran tinggi pada daerah penelitian dengan pengklasifikasian dari kemiringan terendah yaitu $0 \mathrm{sd} 45 \%$.

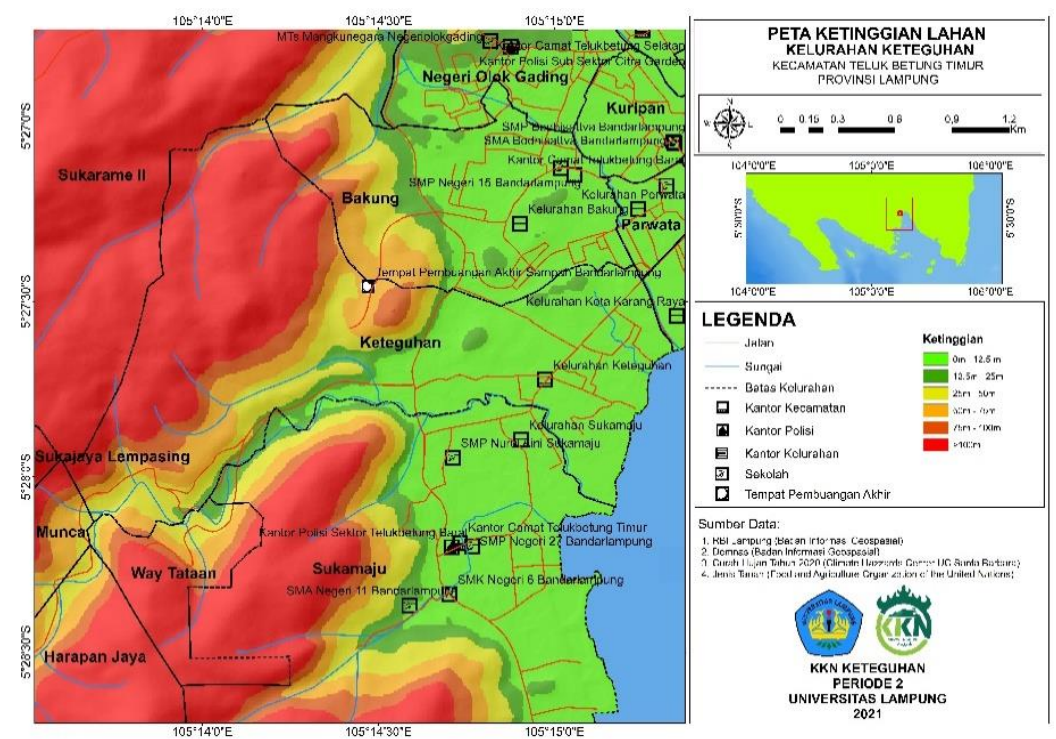

Gambar 2. Peta ketinggian lahan hasil pengklasifikasian data DEM

Parameter ketinggian lahan juga berpengaruh terhadap tingkat kerawanan banjir, peran dari ketinggian lahan sebagai media tingkat kerawanan yaitu apabila pada dataran rendah akan cenderung lebih sering mengalami bencana banjir dibandingkan dengan dataran yang lebih rendah. Pada daerah keteguhan memiliki luasan yang besar untuk di Kecamatan Teluk Betung Timur dimana terdapat dataran tinggi 


\section{Jurnal Pengabdian Kepada Masyarakat BUGUH}

Dipublikasikan

Badan Pelaksana Kuliah Kerja Nyata Universitas Lampung

Sekretariat Badan Pelaksana Kuliah Kerja Nyata, Universitas Lampung, J. Prof. Dr. Soemantri Brojonegoro No. 1, Bandar Lampung 35145.

hingga rendah. Pada peta tersebut daerah keteguhan memiliki ketinggian dari $0-12.5 \mathrm{~m}, 12.5-25 \mathrm{~m}$, $25-50 \mathrm{~m}, 50-75 \mathrm{~m}, 75-100 \mathrm{~m}$ dan $>100 \mathrm{~m}$. Pada daerah keteguhan daerah lebih mendominasi oleh dataran rendah yaitu dengan nilai $0-12.5 \mathrm{~m}$ sehingga pada daerah keteguhan cenderung sering mengalami bencana rawan banjir.

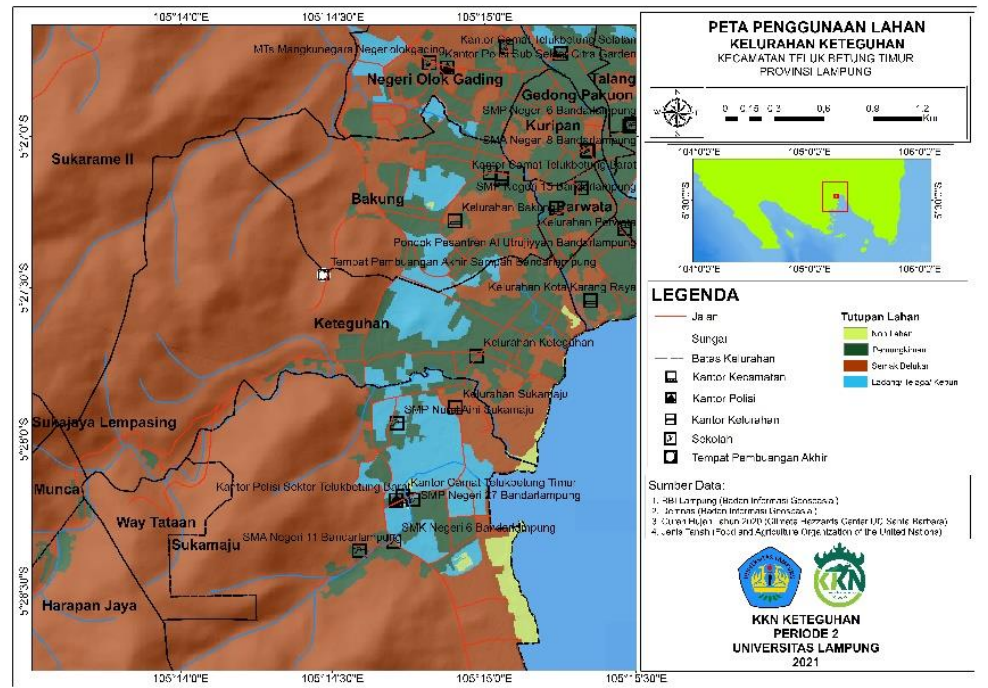

Gambar 3. Peta penggunaan lahan hasil dari proses overlay RBI

Parameter penggunaan lahan juga berperan penting pada proses peningkatan peluang banjir terdapat 4 pengklasifikasian parameter penggunaan lahan meliputi; non lahan, pemukiman, semak belukar dan ladang/telaga/kebun. Dimana pada parameter yang paling besar yaitu pada penggunaan lahan berupa pemukiman. Pada daerah pemukiman cenderung akan mengalami peningkatan potensi rawan banjir, hal ini disebabkan karena kurangnya zona resapan pada daerah pemukiman sehingga pada saat air meluap, banjir akan sulit surut. Dibandingkan dengan daerah yang memiliki penggunaan lahan berupa semak belukar, dimana pada daerah tersebut masih terdapat zona serapan untuk air agar tidak mengalami kelebihan muatan volume air.

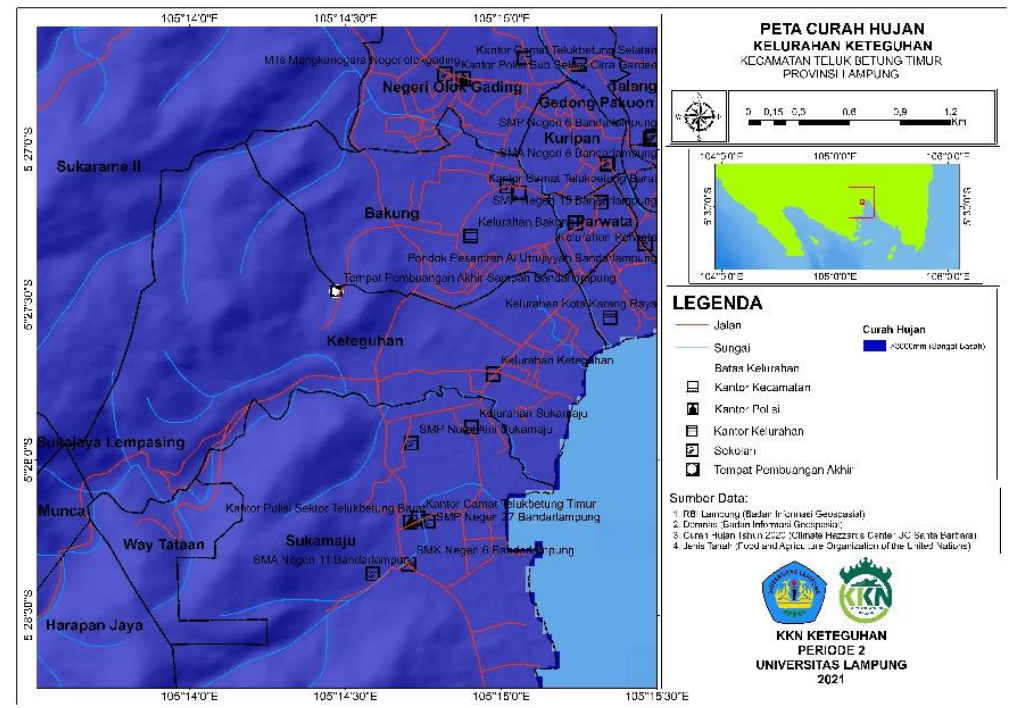

Gambar 4. Peta curah hujan hasil interpolasi indeks distance weighting

Salah satu parameter lainnya yang paling berpengaruh pada daerah keteguhan untuk peningkatan daerah rawan banjir ialah parameter curah hujan. Curah hujan merupakan titik ukur pola sebaran hujan yang 


\section{Jurnal Pengabdian Kepada Masyarakat BUGUH}

Dipublikasikan

Badan Pelaksana Kuliah Kerja Nyata Universitas Lampung

Sekretariat Badan Pelaksana Kuliah Kerja Nyata, Universitas Lampung, J. Prof. Dr. Soemantri Brojonegoro No. 1, Bandar Lampung 35145.

terjadi pada suatu wilayah. Apabila curah hujan tinggi maka daerah tersebut akan mengalami intensitas hujan yang tinggi. Pada daerah keteguhan rata-rata data curah hujan tahunan yang terjadi pada daerah tersebut kisaran $>3000 \mathrm{~mm} /$ tahun dimana angka tersebut merupakan nilai yang sangat tinggi. Sehingga pada daerah keteguhan untuk tahun 2020 cenderung memiliki intensitas hujan yang tinggi dan menyebabkan meningkatnya potensi terjadinya banjir.

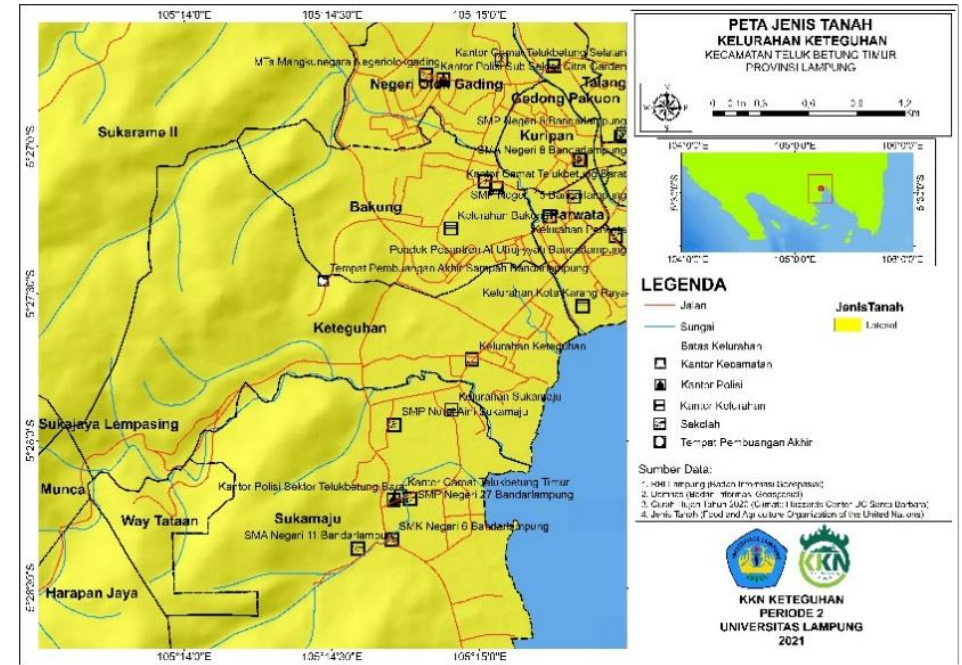

Gambar 5. Peta jenis tanah hasil proses cropping dan klasifikasi

Parameter lain yang mendukung meningkatnya potensi terjadinya rawan banjir yaitu dilihar berdasaran jenis tanah yang terdapat pada daerah penelitian. Pada daerah penelitian dilihat berdasarkan data jenis tanah dari Food and Agriculture Organization of The United Nations daerah keteguhan memiliki jenis tanah yaitu latosol. Jenis tanah sangat diperlukan untuk memetakan rawan banjir, hal ini dilihat berdasarkan karaktersitik tanah tersebut, apabila tanah tersebut memiliki sifat impermeable atau tanah yang susah meloloskan air akan berdampak buruk sehingga dapat meningkatkan peluang terjadinya rawan banjir. Tanah latosol umumnya berada pada daerah yang memiliki jenis iklim basah dan memiliki karakteristik tanah berstruktur remah.

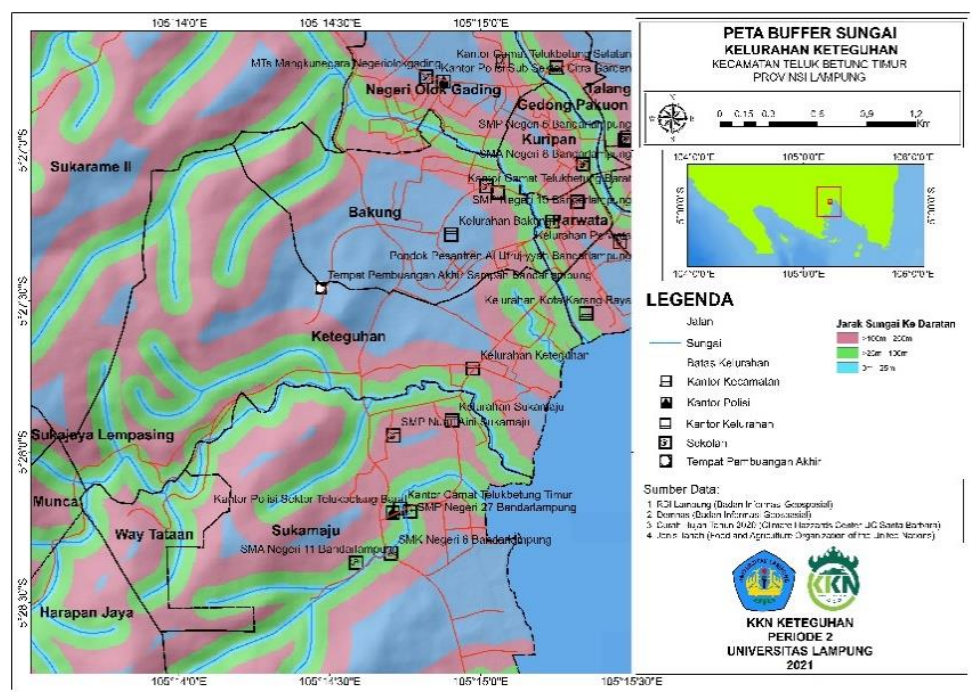

Gambar 6. Peta buffer sungai hasil proses multiple ring buffer 


\section{Jurnal Pengabdian Kepada Masyarakat BUGUH}

Dipublikasikan

Badan Pelaksana Kuliah Kerja Nyata Universitas Lampung

Sekretariat Badan Pelaksana Kuliah Kerja Nyata, Universitas Lampung, J. Prof. Dr. Soemantri Brojonegoro No. 1, Bandar Lampung 35145.

Peta buffer sungai merupakan peta yang dihasilkan dari proses perhitungan jarak dari bibir sungai kearah darat bidang horizontal dari sungai. Pada penelitian kali ini dilakukan proses buffer dengan rentang jarak dari sungai kisaran; $0-25 \mathrm{~m}, 25-100 \mathrm{~m}$ dan $100-250 \mathrm{~m}$. Semakin dekat jarak suatu lokasi terhadap bibir sungai maka akan berpotensi tinggi mengalami bencana banjir. Daerah keteguhan memiliki dua sungai utama yang mengatur pola aliran air pada daerah keteguhan.

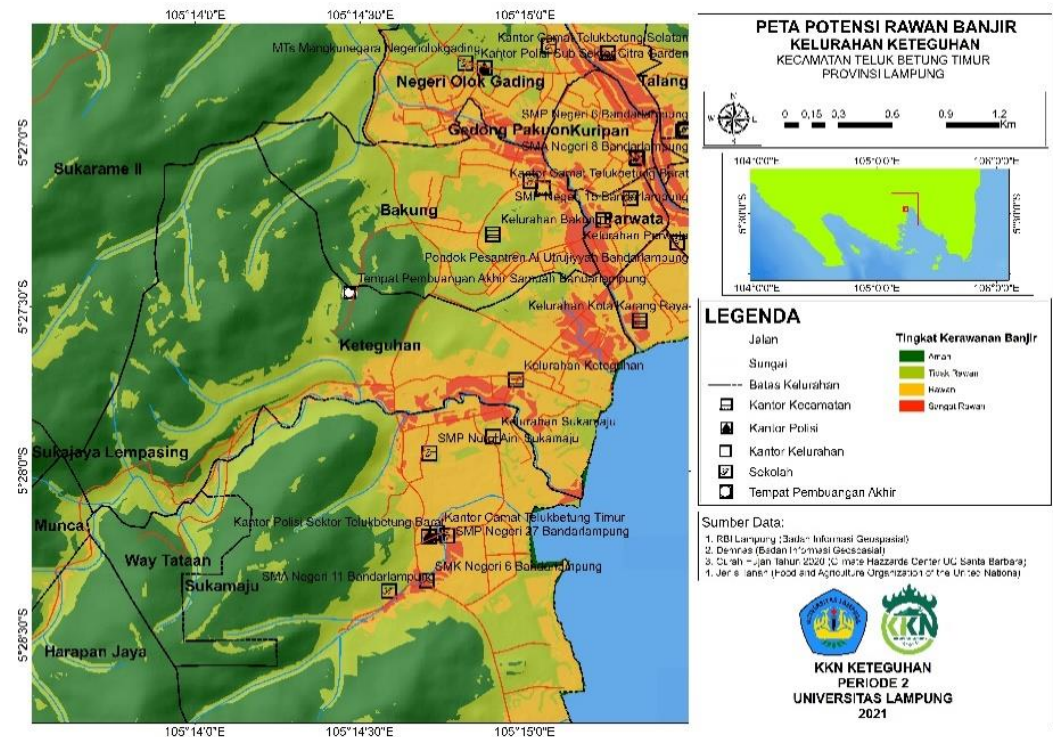

Gambar 7. Peta potensi rawan banjir hasil proses weighted overlay

Tabel 8. Klasifikasi peta potensi rawan banjir di Kelurahan Keteguhan

\begin{tabular}{lcc}
\hline No & Klasifikasi & Luas Area (Ha) \\
\hline 1 & Aman & 137.451 \\
\hline 2 & Tidak Rawan & 92.5116 \\
\hline 3 & Rawan & 62.4922 \\
\hline 4 & Sangat Rawan & 15.7767 \\
\hline
\end{tabular}

Peta potensi rawan banjir didapatkan dengan melalui berbagai proses yang terdiri dari beberapa parameter yang disatukan menggunakan metode weighted overlay, tiap parameter memiliki nilai skor masing-masing yang berpengaruh terhadap hasil dari peta potensi rawan banjir. Peta potensi rawan banjir diklasifikasikan menjadi 4 kategori yaitu aman, tidak rawan, rawan dan sangat rawan. Jika dilihat dari daerah keteguhan pada daerah lingkungan 3 atau daerah umbul kunci memiliki rata-rata potensi rawan bajir dengan kategori tidak rawan dikarenakan daerah tersebut memiliki morfologi yang memiliki ketinggian yang besar. Dan pada daerah umbul kunci bagian daratan rendah terdapat beberapa yang berpotensi terdapat pada daerah dekat sungai utama di jalan zulkarmaen subbing. Terdapat daerah yang berpotensi pada dataran rendah Kelurahan Keteguhan tepatnya berada pada lingkungan 1 dan 2 yang berada di daerah terdekat sungai di arah jalan marthadinata. Jika di lihat secara keseluruhan daerah keteguhan dengan kategori aman memiliki luasan hingga $137.451 \mathrm{Ha}$, kategori daerah tidak rawan memiliki luas area hingga 92. $5116 \mathrm{Ha}$, kategori rawan memiliki luasan hingga 62.4992 Ha dan pada daerah sangat rawan memiliki luas area hingga $15.7767 \mathrm{Ha}$. Pada daerah keteguhan daerah yang berpotensi sangat rawan cenderung memiliki luasan yang rendah sehingga pada kelurahan keteguhan hanya beberapa saja yang sangat berpotensi terjadinya banjir apabila intensitas hujan yang tinggi. 


\section{Jurnal Pengabdian Kepada Masyarakat BUGUH}

Dipublikasikan

Badan Pelaksana Kuliah Kerja Nyata Universitas Lampung

Sekretariat Badan Pelaksana Kuliah Kerja Nyata, Universitas Lampung, J. Prof. Dr. Soemantri Brojonegoro No. 1, Bandar Lampung 35145.

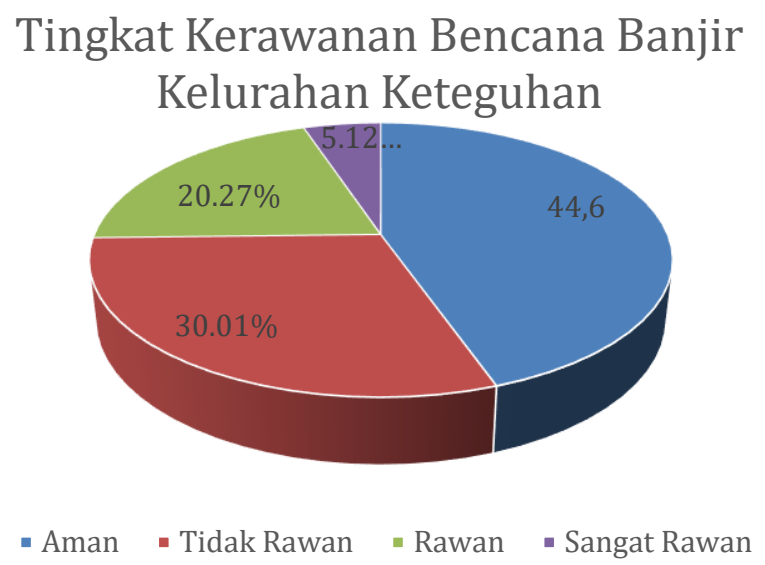

Gambar 8. Persentase tingkat kerawanan banjir pada daerah keteguhan

Hasil persentase dari keseluruhan tingkat kerawanan bencana banjir pada daerah keteguhan dilihat berdasarkan luas areanya, pada kategori aman memiliki persentase $44.6 \%$ dari keseluruhan daerah keteguhan, pada kategori tidak rawan memiliki persentase hingga $30.01 \%$, kategori rawan memiliki persentase hingga $20.27 \%$ dan kategori sangat rawan memiliki persentase $5.12 \%$. Daerah yang memiliki kategori rawan berkemungkinan terjadinya rawan banjir namun tidak terlalu besar sehingga kategori yang sangat diperlukan untuk ditinjau yaitu pada daerah yang memiliki kategori sangat rawan.

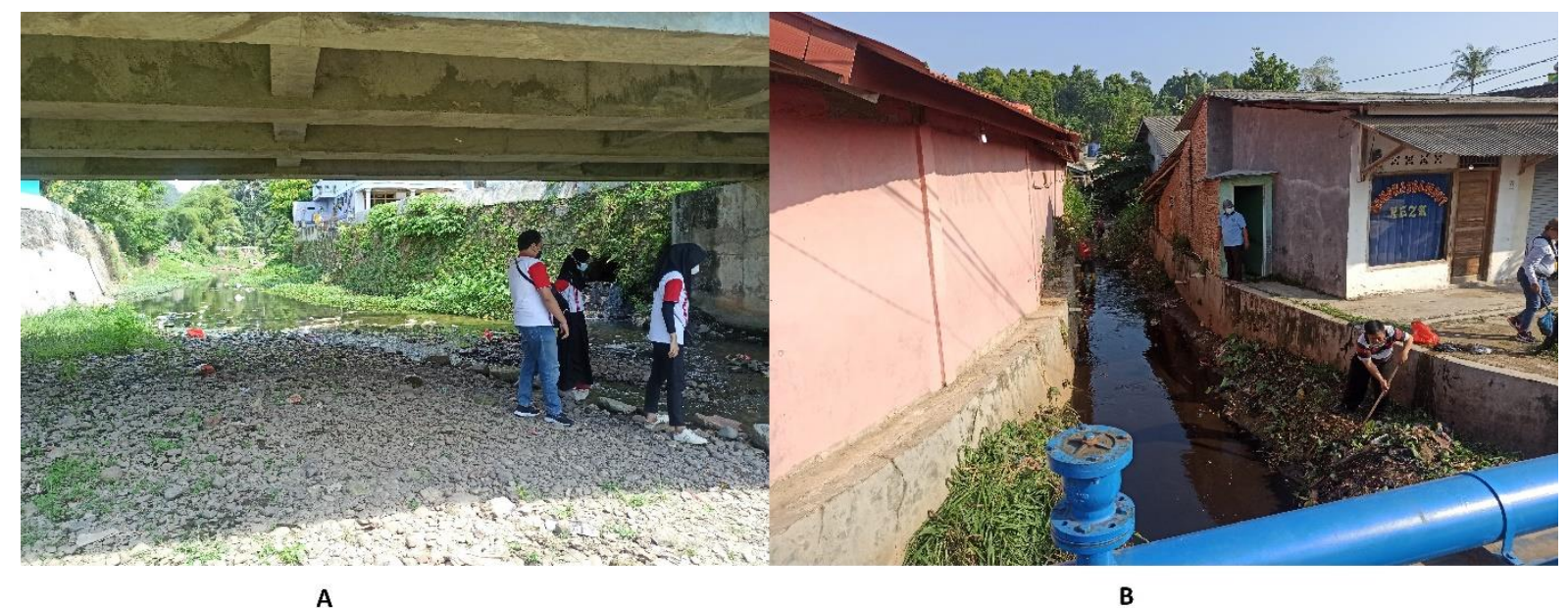

Gambar 9. (A,B)Pengecekan daerah yang berpotensi rawan banjir di kelurahan keteguhan

Selain melakukan proses pembuatan peta rawan banjir juga dilakukan proses monitoring terhadap hasil data tersebut. Jika dilihat pada gambar 9 merupakan kegiatan survei daerah yang memiliki potensi sangat rawan pada peta potensi rawan banjir. Lokasi tersebut terletak pada dua sungai utama daerah Kelurahan Keteguhan yang berada pada jalan Laksamana R. E. Martadinata. Hasil yang didapatkan dari kegiatan tersebut, pada sungai pertama yang berada di dekat kelurahan keteguhan pada gambar 6A merupakan daerah yang pernah mengalami banjir bandang besar pada tahun 2020 dan dikategorikan zona sangat rawan pada peta potensi rawan banjir. Hal ini disebabkan karena adanya perubahan topografi disepanjang sungai sehingga membuat debit air yang ditampung pada bagian hilir sangat deras dan berlebihan, hal ini terjadi pada saat intensitas hujan yang tinggi. Pada sungai gambar 6A juga merupakan sungai utama dari hasil percabangan 3 sungai yang berada pada bagian hulu bertopografi tinggi yang membawa debit air yang sangat deras. Jika dilihat pada sungai gambar 6B merupakan sungai yang kecil, hal tersebut sangat berpotensi mengalami banjir karena kurangnya luas area sungai sehingga 


\section{Jurnal Pengabdian Kepada Masyarakat BUGUH}

Dipublikasikan

Badan Pelaksana Kuliah Kerja Nyata Universitas Lampung

Sekretariat Badan Pelaksana Kuliah Kerja Nyata, Universitas Lampung, J. Prof. Dr. Soemantri Brojonegoro No. 1, Bandar Lampung 35145.

menimbulkan sungai sulit untuk menampung debit air yang tinggi. Namun pada sungai tersebut merupakan sungai tunggal yang tidak memiliki cabang anak sungai pada daerah yang berelevasi tinggi sehingga debit air yang di keluarkan tidak terlalu besar.

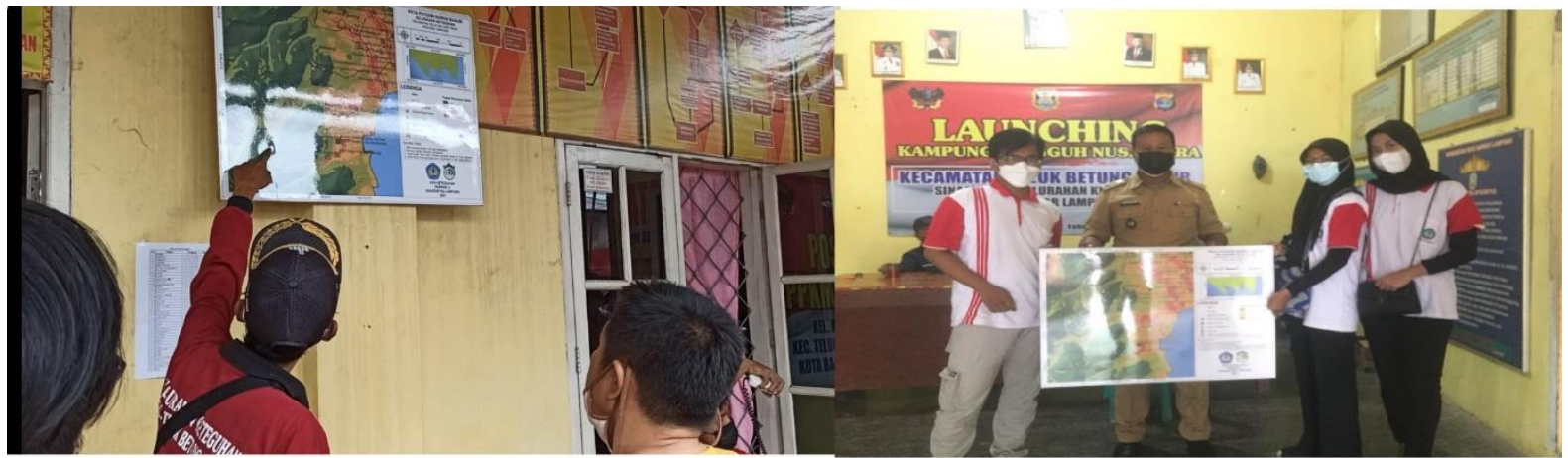

A

B

Gambar 10. (A) Sosialisasi peta rawan banjir, (B) Penyerahan peta potensi rawan banjir ke Kelurahan Keteguhan

Ketika proses pemetaan dan peninjauan kembali daerah potensi rawan banjir dilakukan proses sosialisasi dan penyerahan peta potensi rawan banjir pada pihak Kelurahan Ketaguhan. Sosialisasi dilakukan pada beberapa staff kelurahan yang mana dengan melakukan sosialisasi tersebut harapanya staff kelurahan dapat mengambil Langkah untuk pencegahan mitigasi bencana banjir pra-bencana dan saling berbagi informasi kepada setiap warganya.

\section{Kesimpulan}

Berdasarkan hasil pembahasan penelitian yang telah dilakukan dapat disimpulkan bahwa:

1) Pada daerah keteguhan terdapat daerah yang berpotensi mengalami bencana banjir yang tinggi yaitu pada daerah terdekat sungai di jalan umbul kunci di lingkungan 3 dataran rendah, sepanjang area terdekat sungai pada daerah terdekat Kelurahan Keteguhan Jalan laksamana R.E. Martadinata dan sepanjang area sungai terdekat mushollah nurul Jannah pada Jalan laksamana R.E. Martadinata.

2) Berdasarkan luasan area pada daerah kelurahan keteguhan memiliki tingkat kerawanan bencana banjir yaitu kategori aman memiliki luas hingga $137.451 \mathrm{Ha}$ dengan persentase $44.6 \%$, kategori tidak rawan memiliki luas hingga 95.5116 Ha dengan persentase $30.01 \%$, kategori rawan memiliki luas hingga $62.4922 \mathrm{Ha}$ dengan persentase $20.27 \%$ dan kategori sangat rawan memiliki luas hingga 15.7767 Ha dengan persentase 5.12\%.

3) Faktor yang mempengaruhi pada daerah survei pada area sepanjang sungai terdekat Kelurahan Keteguhan disebabkan oleh tingginya curah hujan dan debit air akibat perbedaan elevasi antara cabang anak sungai kearah sungai utama dan pada area sungai terdekat mussholah nurul Jannah disebabkan karena luas area sungai utama yang kecil namun memiliki pola debit air yang rendah.

\section{Ucapan Terima Kasih}

Puji syukur kepada Allah SWT yang senantiasa kami panjatkan karena hanya dengan rahmat dan hidayah-Nya kami dapat menyelesaikan pengabdian ini. Kami juga banyak mendapatkan dukungan dari berbagai pihak yang telah menyumbangkan pikiran, waktu, tenaga, dan sebagainya. Oleh karena itu, pada kesempatan yang baik ini kami mengucapkan terima kasih kepada:

a) Universitas Lampung

b) BPKKN Universitas Lampung

c) Dosen KDPL Mahasiswa Universitas Lampung

d) Dosen DPL Mahasiswa Universitas Lampung

e) Kepala Desa Keteguhan Kec. Teluk Betung Timur Bandar Lampung 


\section{Jurnal Pengabdian Kepada Masyarakat}

\section{BUGUH}

Dipublikasikan

Badan Pelaksana Kuliah Kerja Nyata

Universitas Lampung

Sekretariat Badan Pelaksana Kuliah Kerja Nyata, Universitas Lampung,

J. Prof. Dr. Soemantri Brojonegoro No. 1, Bandar Lampung 35145.

f) Masyarakat Desa Keteguhan Kec. Teluk Betung Timur Bandar Lampung

Semoga amal dan kebaikan yang diberikan kepada kami akan mendapatkan balasan dari Allah SWT. Aamiin.

\section{Daftar Pustaka}

Adininggar, F., Suprayogi, A., \& Wijaya, A. (2016). Pembuatan Peta Potensi Lahan Berdasarkan Kondisi Fisik Lahan Menggunakan Metode Weighted Overlay. Jurnal Geodesi Undip, 5(2), 136146.

Ajr, E. Q., \& Dwirani, F. (2019). Menentukan stasiun hujan dan curah hujan dengan metode polygon thiessen daerah Kabupaten Lebak. Jurnal Lingkungan Dan Sipil, 2(2), 139-146.

Hardianto, A., Winardi, D., Rusdiana, D. D., Putri, A. C. E., Ananda, F., Devitasari, Djarwoatmodjo, F. S., Yustika, F., \& Gustav, F. (2020). Pemanfaatan Informasi Spasial Berbasis SIG untuk Pemetaan Tingkat Kerawanan Longsor di Kabupaten Bandung Barat, Jawa Barat. Jurnal Geosains Dan Remote Sensing, 1(1), 23-31. https://doi.org/10.23960/jgrs.2020.v1i1.16

Maharani, Nia; Andika, I. K. A. (2020). Tingkat Pengetahuan Siswa Tentang Kesiapsiagaan Bencana Gempa Bumi Di SMPN 3 Kuta Selatan Badung Provinsi Bali. PENDIPA Journal of Science Education, 4(3), 32-38. https://doi.org/10.33369/pendipa.4.3.32-38

Pahrul, Razikin; Rosalina, K. D. A. (2017). Strategi Penangulangan Bencana Banjir Berdasarkan Persepsi Masyarakat Di Kecamatan Barabai Kabupaten Hulu Sungai Tengah. Jurnal Pendidikan Geografi, 4(1), 27.

Tumimomor, Mailany; Jando, Emanuel; Meolbatak, E. (2013). Sistem Informasi Geografis Pariwisata Kota Kupang. Journal Nasional Pendidikan Teknik Informatika, 1(2), 142-152. 